\title{
MITOLOGI UNSUR MISTIK DALAM PERIKLANAN (IKLAN “GO-JEK VERSI KAMU” EPISODE “KUNTI”)
}

\author{
PATRICIA ROBIN \\ Communication Science - Fakultas IImu Sosial dan Humaniora \\ probin@bundamulia.ac.id \\ Universitas Bunda Mulia, Jakarta
}

\begin{abstract}
Communication advances cannot be separated from technological developments. This is also in line with human will, especially urban communities that are increasingly diverse and constantly changing. Referring to this, there are many digital applications offering services that make it easier for people to carry out their daily lives, as well as complementing their lifestyles.

In fulfilling it all, GO-JEK as an application for offering the nation's children makes it easy for loyal customers. Starting from reducing the use of cash, completing features that are close to everyday life, to the newest one is to compile the types of services that are most widely used and placed at the top. This is the basic feature of "GO-JEK Your Version" which is poured in 3 ads with the characteristics of own segmentation.

Each ad is interpreted differently because it has many signs in it that are not independent but are interrelated and neatly arranged with other marks. In the ad that was studied by the researcher, "GO-JEK Your Version" episode "Kunti", researchers saw a shift in meaning from the mystical side, where the main character in the advertisement was not a public figure but Kunti who was once considered a creepy and shunned spirit. The existence of Kunti in this advertisement is reviewed with Semiotics Studies which will break down all the shifts that occur and are seen in the verbal and nonverbal elements of advertising.

The mythology that finally emerged was the Lifestyle Mythology in which there was a shift in cellphones, glasses and fashion; and Transformation Mythology Meanings which include mystical themes and the use of mobile phones among today's society.
\end{abstract}

Keywords : advertising, sign, mean, semiotics, mystical, myth 
National Conference of Creative Industry: Sustainable Tourism Industry for Economic Development

Universitas Bunda Mulia, Jakarta, 5-6 September 2018

ISSN No: 2622-7436

\section{BAB I \\ PENDAHULUAN}

\subsection{Latar Belakang}

Teknologi berkembang dari masa ke masa, menjadikan kehidupan masyarakat semakin dimudahkan. Semua yang dibutuhkan dan diinginkan bisa langsung didapat dengan bantuan telepon genggam semata. Kemudahan ini paling terlihat dalam komunikasi (formal/informal), dimana pertukaran informasi tidak lagi harus dilakukan secara tatap muka, melainkan bisa melalui jarak jauh, baik itu pesan singkat, media sosial, ataupun telepon video.

Selain komunikasi, kehidupan sosial, budaya, bahkan tranportasi tidak dipungkiri terkena imbas kemajuan teknologi tersebut. Dampak positif itu antara lain masyarakat dimudahkan jika ingin bepergian, tanpa perlu memiliki atau menggunakan kendaraan pribadi. Walaupun Indonesia terkesan terlambat dalam menerapkan transportasi online, tetapi nyatanya rivalitas tinggi langsung hadir dari dua perusahaan terbesar, yaitu Grab dan GO-JEK.

Mengusung identitas sebagai Karya Negeri, Karya Pemuda Bangsa, GO-JEK adalah sebuah perusahaan teknologi berjiwa sosial yang bertujuan meningkatkan kesejahteraan pekerja di berbagai sektor informal di Indonesia. Memulai terobosan sejak tahun 2010 dimana dengan bermodalkan telepon genggam, masyarakat akan dimudahkan menemukan transportasi roda dua (Ojek), GO-JEK kini menjadi ondemand mobile platform dan aplikasi terdepan yang menyediakan berbagai layanan lengkap mulai dari transportasi, logistik, pembayaran, layan-antar makanan, dan lainnnya.

Terdapat 3 nilai pokok yang dijunjung GO-JEK, antara lain kecepatan, inovasi, dan dampak sosial. Hal ini diimplementasikan dalam ragam pengembangan yang terkesan sederhana tetapi ternyata berdampak ke masyarakat. Sebut saja GO-PAY, sebuah layanan yang memberikan kemudahan bertransaksi, tanpa menggunakan uang tunai; GO-POINTS, sebuah keuntungan point tambah bagi pengguna setia GO-JEK, dimana point-point tersebut dapat ditukarkan dengan potongan discount hingga jasa gratis dari aplikasi GO-JEK; dan yang teranyar adalah menyusun sendiri "GO-JEK VERSI KAMU" dengan keleluasaan pengguna untuk menetapkan 7 layanan favorit untuk diletakkan di paling atas.

Lantas bagaimana proses masyarakat mengetahui dan memanfaatkan ragam kemudahan ini? Penggunaan iklan tidak dipungkiri menjadi begitu penting untuk memberitahukan kepada masyarakat adanya perbaikan dan pengembangan ini. Iklan dilakukan dalam berbagai platform, salah satunya Media Baru Youtube.

GO-JEK menyajikan iklan yang berbeda dalam setiap episodenya. Terdapat tanda pagar atau tagar (hashtag) yang menjadi penanda iklan tersebut. Seperti \#hiduptanpabatas yang biasa menggunakan public figure sebagai pemeran utama, atau \#CeritaGOJEK yang menceritakan keseharian dari para mitra driver ojek online. Tagar ini juga yang menjadi identitas dari \#GOJEKVersiKamu dengan 3 episode berbeda.

Salah satu yang menarik adalah Iklan \#GOJEKVersiKamu versi "Kunti". Di iklan ini digambarkan sosok Kuntilanak atau Kunti yang menggunakan aplikasi GO-JEK lalu 
National Conference of Creative Industry: Sustainable Tourism Industry for Economic Development

Universitas Bunda Mulia, Jakarta, 5-6 September 2018

ISSN No: 2622-7436

menyusun sendiri, jasa mana yang menjadi favorit. Terdapat 2 versi lain, yaitu "Gozali" dan "Announcer Bioskop", dengan skenario yang kurang lebih sama, tetapi ingin merengkuh pangsa pasar yang berbeda.

Kuntilanak atau Kunti merupakan sosok seram yang menjadi "bahan menakutnakuti" anak zaman dahulu, tetapi dengan iklan "GOJEK Versi Kamu” cenderung menjadi bahan lelucon. Maka berdasarkan uraian di atas, peneliti tertarik untuk memaknai dan melihat pergeseran makna yang terjadi, yaitu ketika sosok mistis yang dahulu jarang terlihat bahkan cenderung disegani, kini beralih fungsi menjadi sosok menghibur dan disukai oleh masyarakat.

\subsection{Identifikasi Masalah}

Penelitian ini berfokus pada iklan "GO-JEK VERSI KAMU". Terdapat 3 versi iklan ini, antara lain "Gozali", "Kunti", dan "Announcer Bioskop". Terdapat perbedaan segmentasi yang ingin diraih dari ketiga iklan ini, terbukti dengan "Susunan Versi Kamu" yang berbeda dari ketiga iklan tersebut. Menempati urutan ke-2 dari 3 versi, Iklan "GO-JEK Versi Kamu" Episode "Kunti" menarik untuk diteliti. Iklan ini diluncurkan pada 13 April 2018 ini dan menyedot 3.950.210 viewers (per 2 Agustus 2018 PKI 12.15 WIB) dengan total 211 Komentar. Judul yang diusung oleh akun Youtube GO-JEK Indonesia, terdengar janggal, juga menarik. Kuntilanak (bahasa Melayu: Pontianak atau Puntianak) adalah hantu yang dipercaya berasal dari perempuan hamil yang meninggal dunia atau wanita yang meninggal karena melahirkan dan anak tersebut belum sempat lahir. Nama "puntianak" merupakan singkatan dari "perempuan mati beranak", sering disingkat "kunti".

Makhluk halus atau hantu yang selama ini dikenal dengan citra menyeramkan, kini beralih menjadi sosok pengisi sebuah iklan. Bukan lagi menakutkan, iklan ini menuai komentar positif, seperti "lucu", "kocak", dan lainnya yang bernada samasama menyenangkan.

Di tengah keberagaman ide, budaya, konsep, hingga selebritas yang ada di Indonesia, GO-JEK ingin mengedepankan sisi "inovatif" dalam iklannya. Tampilan fisik kuntilanak (hantu) yang menyeramkan bertentangan dengan narasi dan gesture-nya yang lucu. Berdasarkan deskripsi identifikasi masalah tersebut, maka penelitian ini ditujukan untuk menjawab pertanyaan:

1. Bagaimana pemaknaan atas tanda verbal dan nonverbal yang muncul dari sosok Kuntilanak dalam Iklan "GO-JEK Versi Kamu" ketika menggunakan aplikasi GO-JEK?

2. Bagaimana mitologi sosok Kuntilanak dalam Iklan "GO-JEK Versi Kamu"?

Berdasarkan rumusan masalah di atas, maka penelitian ini dilaksanakan dengan tujuan:

1. Untuk memaparkan pemaknaan yang muncul atas setiap tanda verbal dan nonverbal yang muncul dari sosok Kuntilanak dalam Iklan "GO-JEK Versi Kamu" ketika menggunkan aplikasi GO-JEK?

2. Untuk memaparkan mitologi sosok Kuntilanak dalam Iklan "GO-JEK Versi Kamu". 
National Conference of Creative Industry: Sustainable Tourism Industry for Economic Development

Universitas Bunda Mulia, Jakarta, 5-6 September 2018

ISSN No: 2622-7436

\section{BAB II \\ KAJIAN PUSTAKA}

\subsection{Iklan}

Beragam media atau sarana digunakan perusahaan untuk mengenalkan hingga menanamkan brand positioning dalam benak konsumennya. Semua itu kita kenal dengan istilah iklan atau yang didefinisikan sebagai bentuk komunikasi nonpersonal mengenai organisasi, produk, servis, atau ide yang dibayar oleh satu sponsor yang diketahui. Istilah "dibayar" menunjukkan fakta bahwa ruang atau waktu bagi suatu pesan iklan pada umumnya harus dibeli. Maksud kata "nonpersonal" berarti suatu iklan melibatkan media massa yang dapat mengirimkan pesan kepada sejumlah besar kelompok individu pada saat bersamaan. Oleh karena itu, sifat nonpersonal iklan berarti pada umumnya tidak tersedia kesempatan untuk mendapatkan umpan balik yang segera dari penerima pesan (Morissan, 2010:17-18).

Iklan merupakan salah satu bentuk promosi yang paling dikenal dan paling banyak dibahas orang. Hal ini tak terlepas dari daya jangkau yang luas. Iklan pun menjadi suatu instrumen promosi yang penting, khususnya bagi perusahaan yang memproduksi barang atau jasa yang ditujukan pada masyarakat luas (Morissan, 2010:17-18).

Iklan disebut juga "advertising" memiliki peran utama dalam dunia bisnis dan masyarakat, antara lain :

a. Pemasaran

Proses bisnis yang biasanya dimaksudkan untuk memenuhi kebutuhan dan keinginan konsumen dengan menyediakan barang dan jasa dinamakan pemasaran atau marketing. Alat yang digunakan manajer pemasaran dikenal dengan Marketing Mix yang dibagi atas 4Ps yaitu product, price, place, promotion. Berdasarkan kategori ini, maka iklan termasuk dalam bagian promotion.

b. Komunikasi

Advertising adalah bentuk komunikasi, pesan tentang suatu produk yang disampaikan kepada konsumen. Advertising akan menarik perhatian, memberi informasi, dan terkadang sedikit menghibur yang dimaksudkan untuk menimbulkan respon. Advertising juga merupakan bentuk komunikasi pemasaran untuk mencapai suatu tujuan. Tak hanya itu, advertising juga menyampaikan informasi, mengingatkan, menyampaikan pesan persuasif, serta dapat digunakan konsumen untuk memutuskan pilihan produk.

c. Ekonomi

Kontribusi ekonomi dari advertising berasal dari keunggulannya sebagai alat pemasaran massal. Semakin banyak orang yang tahu tentang suatu produk, semakin tinggi penjualannya. Dengan kata lain, sebagian besar ekonomi berpendapat bahwa karena iklan menjangkau kelompok konsumen yang sangat banyak, maka iklan membuat biaya pemasaran lebih hemat, sehingga dapat menurunkan harga untuk konsumen. Di dalam masyarakat yang cenderung makmur, advertising tidak hanya sebagai pemberi informasi tetapi juga menciptakan permintaan akan suatu produk atau brand tertentu.

d. Masyarakat

Advertising juga memiliki peran sosial. Selain memberi informasi tentang produk baru, advertising juga mencerminkan tren fashion dan desain, dan 
National Conference of Creative Industry: Sustainable Tourism Industry for Economic Development

Universitas Bunda Mulia, Jakarta, 5-6 September 2018

ISSN No: 2622-7436

memperkaya wawasan estetika. Advertising juga mempunyai peran edukasional karena ia mengajarkan tentang produk baru dan kegunaannya. Iklan menunjukkan keragaman dunia tempat yang kita tinggali (Moriarty, dkk, 2011:11-14).

\subsubsection{Media Iklan}

Media memainkan peranan penting dalam iklan. Media advertising merupakan wadah atau alat yang digunakan oleh organisasi atau perusahaan untuk menyampaikan pesan kepada khalayak. Pemilihan media yang tepat sangatlah penting untuk perusahaan, sehingga dapat dipastikan, media tersebut adalah yang paling efektif supaya pesan yang disampaikan tepat sasaran.

Menurut Kotler dan Keller (2007:253) perencanaan media harus mengetahui kemampuan jenis-jenis media utama untuk menghasilkan jangkauan, frekuensi dan dampak. Berikut ini adalah jenis-jenis media yang digunakan dalam periklanan :

Tabel 2.1 : Jenis-jenis Media Utama Periklanan

\begin{tabular}{|c|c|c|}
\hline Media & Keunggulan & Keterbatasan \\
\hline Televisi & $\begin{array}{ll}\text { - } & \text { Menggabungkan gambar,suara,gerakan } \\
\text { - } & \text { Merangsang indera } \\
\text { - } & \text { Perhatian tinggi } \\
\text { - } & \text { Jangkauan luas } \\
\end{array}$ & $\begin{array}{ll}\text { - } & \text { Biaya tinggi } \\
\text { - } & \text { Kekacauan tinggi } \\
\text { - } & \text { Paparan bergerak kilat } \\
\text { - } & \text { Pemilihan audiens kurang } \\
\end{array}$ \\
\hline Radio & $\begin{array}{l}\text { - Penggunaan massal } \\
\text { - } \quad \text { Pemilihan geografis dan demografis } \\
\text { tinggi } \\
\text { - } \quad \text { Biaya rendah } \\
\end{array}$ & $\begin{array}{ll}\text { - } & \text { Hanya suara } \\
\text { - } & \text { Perhatian lebih rendah daripada tv } \\
\text { - } & \text { Struktur harga tidak standar }\end{array}$ \\
\hline Telepon & $\begin{array}{l}\text { - } \quad \text { Banyak pengguna } \\
\text { - } \quad \text { Memberikan sentuhan pribadi }\end{array}$ & $\begin{array}{ll}\text { - } & \text { Biaya relatif tinggi jika digunakan } \\
& \text { sukarelawan }\end{array}$ \\
\hline Internet & $\begin{array}{ll}\text { - } & \text { Pemilihan audiens tinggi } \\
\text { - } & \text { Interaktif } \\
\text { - } & \text { Biaya relatif rendah } \\
\end{array}$ & $\begin{array}{l}\text { - Media relatif baru dengan jumlah } \\
\text { pengguna yang rendah }\end{array}$ \\
\hline Koran & $\begin{array}{ll}\text { - } & \text { Fleksibilitas } \\
\text { - } & \text { Ketetapan waktu } \\
\text { - } & \text { Jangkauan pasar lokal yang baik } \\
\text { - } & \text { Penerimaan luas } \\
\text { - } & \text { Tingkat kepercayaan tinggi } \\
\end{array}$ & $\begin{array}{l}\text { - Usia penggunaan pendek } \\
\text { - } \quad \text { Mutu reproduksi jelek }\end{array}$ \\
\hline $\begin{array}{l}\text { Surat } \\
\text { Langsung } \\
\text { (direct mail) }\end{array}$ & $\begin{array}{ll}\text { - } & \text { Audiens terpilih } \\
\text { - } & \text { Fleksibilitas } \\
\text { - } & \text { yang sama ada persaingan iklan dalam media } \\
\text { - } & \text { Personalisasi } \\
\end{array}$ & $\begin{array}{l}\text { - } \quad \text { Biaya relatif tinggi } \\
\text { - } \quad \text { Citra "surat sampah" atau junk } \\
\text { mail }\end{array}$ \\
\hline Majalah & $\begin{array}{ll}\text { - } & \text { Pemilihan geografis dan demografis tinggi } \\
\text { - } & \text { Penerusan pembacaan baik } \\
\text { - } & \text { Reproduksi bermutu tinggi } \\
\end{array}$ & $\begin{array}{l}\text { - } \quad \text { Perencanaan pembelian iklan } \\
\text { panjang } \\
\text { - Sebagian sirkulasi sia-sia }\end{array}$ \\
\hline
\end{tabular}


National Conference of Creative Industry: Sustainable Tourism Industry for Economic Development

Universitas Bunda Mulia, Jakarta, 5-6 September 2018

ISSN No: 2622-7436

\begin{tabular}{|c|c|c|}
\hline & - Usia penggunaan panjang & - Tidak ada jaminan posisi \\
\hline $\begin{array}{l}\text { Media Luar } \\
\text { Ruang } \\
\text { (billboard) }\end{array}$ & $\begin{array}{ll}\text { - } & \text { Fleksibilitas } \\
\text { - Pengulangan paparan tinggi }\end{array}$ & $\begin{array}{l}\text { - } \quad \text { Pemilihan audiens terbatas } \\
\text { - } \quad \text { kreativitas terbatas }\end{array}$ \\
\hline Yellow Pages & $\begin{array}{l}\text { - Liputan lokal sangat bagus } \\
\text { - Tingkat kepercayaan tinggi } \\
\text { - Jangkauan luas biaya rendah }\end{array}$ & $\begin{array}{ll}\text { - } & \text { Persaingan tinggi } \\
\text { - } & \text { Perencanaan pembelian iklan } \\
& \text { panjang } \\
\text { - } & \text { Kreativitas terbatas } \\
\end{array}$ \\
\hline Brosur & $\begin{array}{ll}\text { - } & \text { Fleksibilitas } \\
\text { - } & \text { Terkendali penuh }\end{array}$ & $\begin{array}{l}\text { - Produksi berlebibah dapat } \\
\text { menyebabkan biaya hilang sia-sia }\end{array}$ \\
\hline
\end{tabular}

\subsection{Semiotika}

Semiotika berasal dari kata Yunani "semeion", yang berarti tanda. Sedangkan semiotika atau semiologi adalah studi tentang tanda dan cara tanda-tanda itu bekerja (Fiske, 2004). Dua tokoh pelopor metode semiotika yakni Ferdinand de Saussure (18571913) dan Charles Sander Peirce (1839-1914). Menurut Saussure, semiologi didasarkan pada anggapan bahwa perbuatan dan tingkah laku manusia akan membawa sebuah makna, serta makna suatu tanda bukanlah makna bawaan melainkan dihasilkan lewat sistem tanda yang dipakai dalam kelompok orang tertentu. Peirce berpendapat bahwa penalaran manusia senantiasa dilakukan lewat tanda, artinya manusia hanya mampu bernalar melalui tanda (Sunardi, 2004).

Semiotika bukanlah ilmu yang mempunyai sifat kepastian, ketunggalan dan objektivitas, melainkan dibangun oleh pengetahuan yang lebih terbuka bagi aneka interpretasi, diketahui bahwa logika interpretasi bukanlah logika matematis, yang hanya mengenal kategori benar atau salah. Logika semiotik adalah logika di mana interpretasi tidak diukur berdasarkan salah atau benarnya, melainkan derajat kelogisannya (Tinarbuko, 2008).

Semiotika adalah ilmu yang mencoba menjawab pertanyaan mengenai apakah sebenarnya $X$ ? Jawabannya, $X$ dapat berupa apapun, mulai dari sebuah kata, isyarat, sampai dengan keseluruhan komposisi musik dan film. Jangkauan $\mathrm{X}$ bisa bervariasi tetapi dirumuskan oleh sifat dasar yang sama. Jika makna $\mathrm{X}$ dituliskan dengan $\mathrm{Y}$, maka tugas utama analisis semiotika adalah mencari relasi antara X dan Y. Sebagai contoh, sebut saja kata red, dalam bahasa Indonesia bisa diartikan sebagai warna primer merah. Tetapi apabila red ada pada lampu lalu lintas, maka diartikan sebagai berhenti; atau pada pesta politik, red bisa diartikan partai politik tertentu, atau turning red pada muka seseorang, bisa berarti kiasan atas mukanya yang memerah (Danesi, 2004:5-6).

\subsubsection{Semiotika Roland Barthes}

Dalam perjalanannya, de Saussure memiliki pengikut yang mengembangkan semiotika struktural dalam suatu bentuk yang lebih maju. Ia adalah Roland Barthes (1915 - 1980) yang terkenal dengan model signifikansi dua tahap atau masuk dalam kajian post-struktural. Barthes sebagai penerus Saussure mengadopsi sistem tanda penanda dan petanda dan menyusun model sistematik untuk menganalisis negosisasi dan gagasan makna interaktif yang berujung pada gagasan dua tatanan pertandaan (order of signification). 
National Conference of Creative Industry:

Sustainable Tourism Industry for Economic Development

Universitas Bunda Mulia, Jakarta, 5-6 September 2018

ISSN No: 2622-7436

Model Barthes yang mengangkat mengenai denotasi dan konotasi kebanyakan digunakan untuk menganalisis tanda berbentuk karya fisik yang dapat diindrai oleh manusia seperti karya sastra dan gejala kebudayaan, mode pakaian, lirik lagu, film dan lainnya. Bagi Barthes komponen tanda, penanda - petanda terdapat juga pada tanda yang bukan berbentuk bahasa, yaitu pada mitos yang merupakan keseluruhan sistem citra dan kepercayaan yang dibentuk masyarakat untuk mempertahankan dan menonjolkan identitasnya (de Saussure,1988).

\subsubsection{Mitologi}

Ciri khas dari kajian semiotika Roland Barthes adalah pada penggunan mitos. Teori mitos dikembangkan oleh Barthes untuk melakukan kritik atas ideologi budaya massa atau budaya media. Mitos adalah suatu wahana dimana ideologi berwujud. Mitos dapat berangkai menjadi mitologi yang memainkan peranan penting dalam kesatuan-kesatuan budaya. Sedangkan Van Zoest (1991) menegaskan, siapapun bisa menemukan ideologi dalam teks dengan jalan meneliti konotasi-konotasi yang terdapat di dalamnya (Indiwan, 2011:17).

Mitos bukanlah tanda yang netral melainkan menjadi penanda untuk memainkan pesan-pesan tertentu yang boleh jadi berbeda sama sekali dengan makna asalnya. Produksi mitos membantu pembaca menggambarkan situasi sosial budaya, mungkin juga politik yang ada disekelilingnya. Beberapa ciri yang terdapat pada mitos adalah sifatnya yang distorsif dan deformatif (konsep mendistorsi form sehingga makna pada sistem tingkat pertama bukan lagi merupakan makna yang menunjuk pada makna yang sebenarnya); Intensional (tidak terjadi begitu saja melainkan karena kesengajaan yang diciptakan, dikonstruksikan oleh budaya masyarakat dengan maksud dan pengertian tertentu); Statement of fact (menaturalisasikan pesan sehingga diterima sebagai sebuah kebenaran yang tidak perlu diperdebatkan dan terletak secara alami dalam nalar awam); dan motivasional (diciptakan dengan melakukan seleksi terhadap berbagai kemungkinan konsep yang akan digunakan bersama sistem semiotik tingkat pertama). Menurut Barthes, mitos adalah tipe wicara, sistem komunikasi dan sebuah pesan. Mitos tidak bisa menjadi sebuah objek, konsep atau ide. Mitos adalah bentuk cara penandaan yang identik dengan "perampokan bahasa" (Halim, 2012:126).

Selanjutnya, penggunaan makna konotasi di masyarakat secara terus menerus akan membentuk suatu ideologi atau makna tingkat ketiga. Secara etimologis ideologi berasal dari bahasa Greek, terdiri atas kata idea (Idein) yang berarti melihat dan logos (logia) yang berarti kata-kata atau pengetahuan dan teori. Tidak ada satupun aktivitas penggunaan tanda yang bukan ideologi karena ideologi sangat dominan dalam eksistensinya (bukan dalam hal esensi). Ideologi merupakan kesadaran semu yang menjadi sistem kepercayaan yang dibuat-buat kemudian menjadi pegangan bagi individu untuk menggunakannya sebagai suatu "bahasa" sehingga membentuk orientasi sosial dan akhirnya berusaha berperilaku selaras dengan ideologi (Indiwan, 2011:18).

\subsubsection{Elemen Gambar pada tayangan}

Dibangun atas susunan tanda yang penuh ideologi, kiranya sajian gambar yang tersaji secara audio visual juga memiliki tujuan terselubung dalam penyajian gambarnya. Hal ini terkait teknik penggunaan kamera, lensa yang digunakan, ataupun penentuan sudut pandang, fokus dan warna. Keterangan lebih lengkap tersaji dalam beberapa tabel di bawah ini (Selby \& Cowdery, 1995:57-58). 
National Conference of Creative Industry: Sustainable Tourism Industry for Economic Development

Universitas Bunda Mulia, Jakarta, 5-6 September 2018

ISSN No: 2622-7436

Tabel 2.1.

Elemen-elemen Dalam Gambar

(Teknik Pengambilan Gambar)

\begin{tabular}{|c|c|}
\hline $\begin{array}{c}\text { Penanda (Signifier) } \\
\text { Teknik Pengambilan Gambar }\end{array}$ & $\begin{array}{c}\text { Petanda (Signified) } \\
\text { Makna }\end{array}$ \\
\hline Big close up & Emosi, dramatis, moment penting \\
\hline $\begin{array}{c}\text { Close up } \\
\text { (Hanya wajah) }\end{array}$ & Intimitas, kedekatan \\
\hline $\begin{array}{c}\text { Medium Shot } \\
\text { (Hampir seluruh tubuh) }\end{array}$ & Hubungan personal intens dengan subjek \\
\hline $\begin{array}{c}\text { Long Shot } \\
\text { (setting dan karakter) }\end{array}$ & Konteks, perbedaan publik \\
\hline
\end{tabular}

Tabel 2.2.

Elemen-elemen Dalam Gambar

(Sudut Pengambilan Gambar)

\begin{tabular}{|c|c|}
\hline $\begin{array}{c}\text { Penanda (Signifier) } \\
\text { Sudut Pengambilan Gambar }\end{array}$ & $\begin{array}{c}\text { Petanda (Signified) } \\
\text { Makna }\end{array}$ \\
\hline High Level & Dominasi, kekuasaan, otoritas \\
\hline Eye Level & Kesejajaran, kesamaan sederajat \\
\hline Low Level & Objek dominasi, dikuasai, kurang otoritas \\
\hline
\end{tabular}

Tabel 2.3.

Elemen-elemen Dalam Gambar

(Tipe Lensa yang Digunakan)

\begin{tabular}{|c|c|}
\hline $\begin{array}{c}\text { Penanda (Signifier) } \\
\text { Tipe Lensa }\end{array}$ & $\begin{array}{c}\text { Petanda (Signified) } \\
\text { Makna }\end{array}$ \\
\hline Wide Angle & Dramatis \\
\hline Normal & Normalitas dan keseharian \\
\hline Telephoto & Tidak personal (Vyeuristic) \\
\hline
\end{tabular}


National Conference of Creative Industry: Sustainable Tourism Industry for Economic Development

Universitas Bunda Mulia, Jakarta, 5-6 September 2018

ISSN No: 2622-7436

\section{BAB III \\ METODE PENELITIAN}

\subsection{Metode Penelitian}

Metode penelitian yang dipakai dalam penelitian ini menggunakan pendekatan kualitatif. Kualitatif itu sendiri menggunakan multi metode dalam hal fokus penelitian, di mana melibatkan proses interpretasi pada kondisi subyek yang alamiah (Denzin \& Lincoln, 1994).

Penelitian ini mengambil kajian kualitatif semiotika dari Roland Barthes yang menganalisis makna tanda dengan fokus perhatian signifikansi dua tahap. Lewat model ini, Barthes menjelaskan bahwa signifikansi tahap pertama merupakan hubungan antara signifier dan signified di dalam sebuah tanda terhadap realitas external atau biasa disebut denotasi yaitu makna paling nyata dari tanda. Sementara konotasi adalah signifikansi tahap kedua yang menggambarkan interaksi ketika tanda bertemu dengan perasaan atau emosi serta nilai kebudayaan dari pembacanya (Indiwan, 2011:16-17).

\subsection{Analisis Semiotika}

Dalam penelitian ini, peneliti mengambil menggunakan pendekatan kualitatif dengan analisis semiotik Roland Barthes.

Yang membedakan semiotika Barthes dengan semiotika lain adalah keberadaan mitos. Menurut Susilo (2000:24), suatu teknik yang menarik dan memberikan hasil yang baik untuk masuk ke dalam titik tolak berpikir ideologis adalah mempelajari mitos. Mitologi atau kesatuan mitos-mitos yang koheren menyajikan inkarnasi maknamakna yang mempunyai wadah dalam ideologi. Ideologi harus dapat diceritakan dan cerita itulah yang disebut dengan mitos. Hal ini merupakan suatu wahana dimana ideologi berwujud. Mitos dapat terangkai menjadi mitologi yang memainkan peranan penting dalam kesatuan-kesatuan budaya. Dengan mudah, kita dapat menemukan ideologi dalam teks dengan jalan meneliti konotasi-konotasi yang terdapat di dalamnya (van Zoest, 1991:70).

\subsection{Unit Analisis}

Dalam penelitian ini, peneliti mengkaji iklan "GO-JEK Versi Kamu" Episode "Kunti". Peneliti mengambil keseluruhan iklan untuk mengetahui makna di balik iklan tersbeut. Dalam proses ini, iklan dibagi ke dalam 6 Scene.

\subsection{Waktu Penelitian}

Jangka waktu penelitian ini berlangsung selama April hingga Agustus 2018. 
National Conference of Creative Industry:

Sustainable Tourism Industry for Economic Development

Universitas Bunda Mulia, Jakarta, 5-6 September 2018

ISSN No: 2622-7436

\section{BAB IV \\ HASIL PENELITIAN \& PEMBAHASAN}

\subsection{Hasil Penelitian}

Tujuan awal penelitian ini adalah pembongkaran mitos dan ideologi yang terkandung dalam iklan "GO-JEK Versi Kamu" Episode "Kunti". Iklan jasa via online ini tergolong "tidak biasa" sehingga menarik viewers di Youtube. Bukan tanpa alasan, peneliti mencurigai makna terselubung atas tanda verbal dan nonverbal yang disajikan "Kunti" dalam iklan tersebut yang bertema mistis.

Penelitian ini dikaji dengan sistem penandaan bertingkat dari Roland Barthes yang akan membahas denotasi, konotasi, mitos dan berakhir pada ideologi. Pesan yang ada dalam teks ini kemudian akan dibahas dengan membagi ke dalam beberapa kategori, yaitu :

1) Pesan Linguistik

Yaitu pesan yang dikemas dalam suatu bahasa dengan memaparkan kata dan kalimat yang terdapat pada host !nsert Investigasi.

2) Pesan ikonik yang terkodekan

Yaitu konotasi yang muncul dalam gambar atau visual dan akan berfungsi apabila dikaitkan dengan sistem tanda yang lebih luas.

3) Pesan Ikonik yang tak terkodekan

Yaitu denotasi harafiah atau pemahaman langsung dari gambar, tanpa mempertimbangkan kode sosial yang lebih luas

\subsubsection{Pesan Ikonik yang Terkodekan "Kunti" dalam iklan "GO-JEK Versi Kamu"}

Pemahaman mengenai makna tanda nonverbal tidak luput dari pemaknaan dengan pisau analisis Semiotika Roland Barthes. Tanda nonverbal banyak berasal dari visual, gambar yang tersaji di layar, juga gerak tubuh dari "Kunti" (disebut juga tanda tubuh), dikaji lantaran kuatnya nuansa kode di dalamnya. Jenis pesan nonverbal selalu melibatkan konotasi yang tidak mungkin sekedar sinyal fisik melainkan butuh penafisran lebih (Danesi, 2004:254).

Tabel 4.1.

Pesan Ikonik Terkodekan "Kunti”

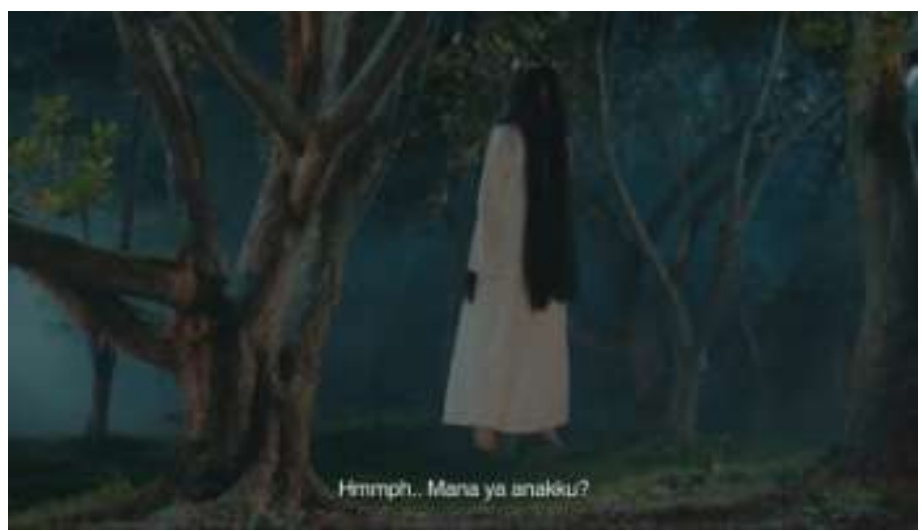


National Conference of Creative Industry:

Sustainable Tourism Industry for Economic Development

Universitas Bunda Mulia, Jakarta, 5-6 September 2018

ISSN No: 2622-7436

\begin{tabular}{|c|c|}
\hline \multicolumn{2}{|c|}{ Gambar 4.1. Scene "Kunti" Mencari Anak (00:03) } \\
\hline Penanda & Petanda \\
\hline $\begin{array}{l}\text { Pengambilan gambar Long Shot dengan } \\
\text { nuansa warna gelap (abu-abu). Subjek } \\
\text { (Kunti) menggunakan pakaian putih, } \\
\text { berada dalam posisi berdiri, melayang di } \\
\text { dahan pohon dengan rambut panjang } \\
\text { hingga sepinggang. Tangan berada di } \\
\text { bawah. Gerakan yang dilakukan hanya } \\
\text { sedikit menggeleng dari sisi kiri ke kanan } \\
\text { secara perlahan. }\end{array}$ & $\begin{array}{l}\text { Memulai iklan dengan tulisan "Kunti Mencari Anak", Iklan } \\
\text { GO-JEK ingin menunjukkan kepada penontonnya, sosok } \\
\text { "Kunti" yang fenomenal tanpa menghilangkan } \\
\text { identitasnya. Pengambilan gambar secara Long Shot } \\
\text { merujuk pada keinginan pengiklan supaya audience bisa } \\
\text { melihat setting keseluruhan. Dahan pohon besar yang ada } \\
\text { di gambar berkorelasi erat dengan kepercayaan masyarakat } \\
\text { bahwa Pohon besar pasti memiliki penghuni atau "isi", } \\
\text { yaitu si makhluk halus atau dalam hal ini adalah "Kunti". } \\
\text { Penggunaan Long shot ini juga ingin menggambarkan } \\
\text { sosok "Kunti" yang jauh dan sama sekali berbeda dengan } \\
\text { manusia pada umumnya (konteks dan perbedaan publik). } \\
\text { Yang semakin membuat scene pada durasi 00:03 menarik } \\
\text { adalah totalitas menyajikan nuansa mistik dalam sebuah } \\
\text { iklan layanan jasa online. Hal ini tergambar dalam nuansa } \\
\text { warna abu-abu di sepanjang iklan tersebut. Pemaknaan } \\
\text { yang terjadi dalam nuansa abu-abu adalah hambar, } \\
\text { berkabut, kabur, dan misteri. Hal ini adalah langkah tepat } \\
\text { lantaran nuansa mistis ingin dibangun dari awal, diiringi } \\
\text { dengan narasi dan intonasi yang menghibur supaya iklan } \\
\text { semakin menarik. }\end{array}$ \\
\hline
\end{tabular}


National Conference of Creative Industry: Sustainable Tourism Industry for Economic Development

Universitas Bunda Mulia, Jakarta, 5-6 September 2018

ISSN No: 2622-7436

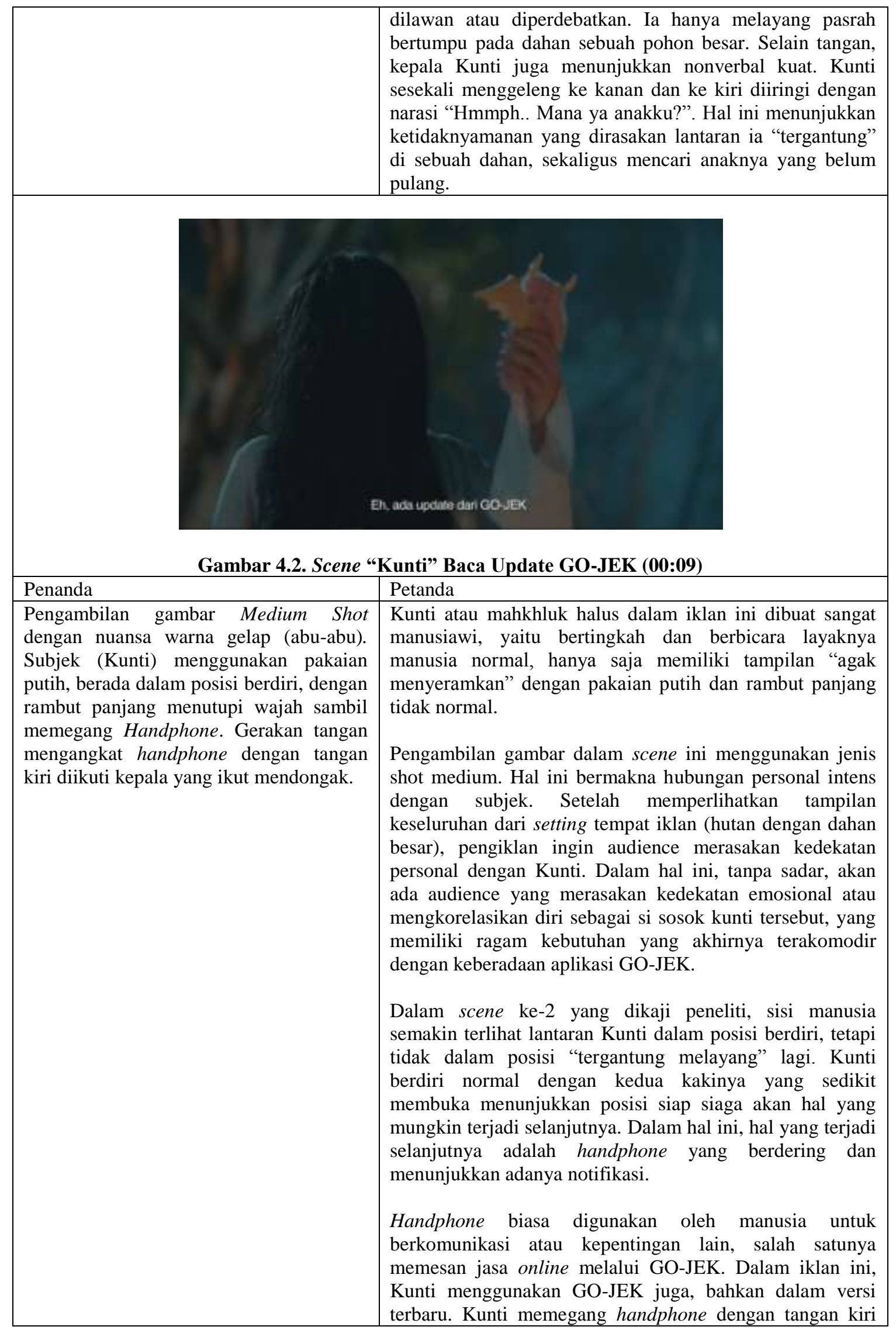


National Conference of Creative Industry:

Sustainable Tourism Industry for Economic Development

Universitas Bunda Mulia, Jakarta, 5-6 September 2018

ISSN No: 2622-7436

\begin{tabular}{|c|c|}
\hline & $\begin{array}{l}\text { dan menggunakan telunjuk kanan untuk menekan } \\
\text { pilihannya. } \\
\text { Memegang Handphone dengan satu tangan diikuti dengan } \\
\text { jari telunjuk lain yang mengoperasikannya dimaknai } \\
\text { sebagai orang yang memilih diam dan tidak berkata apa- } \\
\text { apa. Sosok yang memilih menggunakan gaya ini ketika } \\
\text { memegang handphone memiliki daya tarik tersendiri dan } \\
\text { rela berkorban demi orang lain supaya orang tersebut tidak } \\
\text { tersakiti. Mereka yang menggunakan cara ini ketika } \\
\text { memegang HP cenderung dianggap sukar dimengerti, tetapi } \\
\text { nyatanya hal ini semata karena sukar menemukan yang } \\
\text { cocok dengan kepribadian ini. } \\
\text { Kunti dalam hal ini memang menjadi sosok pendiam secara } \\
\text { verbal dan memilih untuk menyampaikan maksudnya } \\
\text { secara nonverbal atau gestur tubuh. Kunti di sini } \\
\text { dianalogikan sebagai sosok customer GO-JEK, yang } \\
\text { seakan sukar dimengerti apa maunya, nyatanya hal itu } \\
\text { karena belum menemukan yang cocok semata. Aplikasi } \\
\text { GO-JEK dalam hal ini menjadi solusi, yaitu memberikan } \\
\text { kemudahan yaitu salah satunya dengan memberikan fitur } \\
\text { "GO-JEK Versi Kamu", dimana customer bisa dengan } \\
\text { mudahnya menyusun, layanan jasa mana yang menjadi } \\
\text { favorit. } \\
\text { Kepala yang mendongak sambil memegang Handphone } \\
\text { dilakukan oleh Kunti dalam iklan ini. Bukan tanpa sebab, } \\
\text { hal ini bermakna meninggikan dan menyombongkan diri } \\
\text { tanpa ingin kembali menyentuh "tanah". Kunti yang } \\
\text { manusiawi dan menggunakan handphone identik dengan } \\
\text { makna ini, dimana ia merasa sudah jago dalam penggunaan } \\
\text { aplikasi. }\end{array}$ \\
\hline Gambar 4.3. Sce & e "Kunti" Naik GO-RIDE (00:18) \\
\hline Penanda & Petanda \\
\hline $\begin{array}{l}\text { Pengambilan gambar Medium Shot } \\
\text { dengan nuansa warna gelap (abu-abu). } \\
\text { Kunti duduk dibonceng oleh mitra GO- } \\
\text { JEK yang menggunkan Helm dan jaket } \\
\text { berwarna hijau. Pada jaket tersebut } \\
\text { terdapat bendera Indonesia (merah putih) } \\
\text { di sisi kanan, dan tulisan GO-JEK warna }\end{array}$ & $\begin{array}{l}\text { Masih menggunakan jenis shot yang mirip dengan kajian } \\
\text { pada scene sebelumnya. Dalam scene ini, Kunti beradegan } \\
\text { dengan seorang pria yang berperan sebagai Mitra GO-JEK } \\
\text { (Driver Go-Ride). Medium shot dimaksudkan untuk } \\
\text { menunjukkan hubungan personal yang intens dengan } \\
\text { subjek yang ada dalam frame tersebut. Kunti yang semakin } \\
\text { "mirip manusia" ini diharapkan oleh pengiklan identik }\end{array}$ \\
\hline
\end{tabular}


National Conference of Creative Industry: Sustainable Tourism Industry for Economic Development

Universitas Bunda Mulia, Jakarta, 5-6 September 2018

ISSN No: 2622-7436

putih di sisi kiri. Helm yang digunakan juga berwarna hijau dengan kaca yang dibuka di bagian depannya.

Subjek (Kunti) menggunakan helm hijau dan kacamata hitam frame putih. Rambut dominan dalam frame ini lantaran menutupi wajah. Kacamata dipakai tetapi bukan melindungi mata, melainkan menggantung di depan rambut.

Tangan Kunti memegang bahu mitra GOJEK, wajah Mitra GO-JEK menengok ke sisi kanan dengan ekspresi takut, berhadapan dengan wajah Kunti. dengan audience, terutama mereka yang seringkali bepergian menggunakan layanan GO-RIDE. Hal ini tergambar dengan sosok Kunti yang menggunakan helm standard SNI, persis seperti penumpang pada umumnya.

Stone mengemukakakan bahwa pakaian menyampaikan pesan yang dapat dilihat sebelum kata-kata didengar. Hal ini akan bergantung pada sejumlah variabel seperti latar belakang budaya, pengalaman dan lainnya. Sebagai media yang komunikatif, pakaian memiliki beberapa fungsi, salah satunya adalah membedakan seseorang dengan orang lain atau satu kelompok dengan kelompok lainnya. Penggunaan jaket menunjukkan identitas Mitra GO-JEK, dan membedakan ia dengan penumpang atau sesama ojek online lainnya.

Nuansa GO-JEK dan Indonesia sangat terasa dalam shot ini. Mengusung diri sebagai perusahaan karya anak Bangsa, hal ini tergambar jelas dalam warna dan aksen yang terlihat. Secara tampak mata, warna yang dominan dalam scene ini adalah warna hijau, yaitu pada helm Kunti dan Mitra GO-JEK, serta jaket yang digunakan oleh Mitra GOJEK. Warna hijau identik dengan harapan, keterus terangan, kepercayaan, kehidupan, eksistensi. Nilai filosofis ini yang diusung oleh GO-JEK, yaitu menunjukkan kejujuran di mata customer, diikuti kepercayaan yang ingin dipupuk sehingga eksis di tengah persaingan. Tiga pilar utama GO-JEK pun menjadi begitu penting di sini, yaitu kecepatan, inovasi, dan manfaat sosial, yang erat dengan makna warna hijau berupa harapan serta kehidupan.

Emblem bendera merah putih di sisi kanan jaket mitra GOJEK tidak lain menunjukkan identitas GO-JEK yang adalah produk asli Indonesia.. Merah diartikan sebagai wujud hasrat (positif), dan Putih diartikan sebagai wujud kebajikan. Hal ini sejalan dengan Misi dari GO-JEK, dimana salah satunya adalah menjadi perusahaan yang mampu meningkatkan kepedulian dan tanggung jawab terhadap lingkungan sosial. Karya anak bangsa ini ingin diapresiasi di mata dunia. Dengan semakin berkembangnya media sosial, semakin mudah menjadi viral dan terkenal, baik di dunia nyata atau dunia maya. Maka tidak heran, identitas itu ditampilkan di bagian depan (cenderung ke atas) dari jaket Mitra GO-JEK. Hal ini juga sejalan dengan istilah yang sering kita dengar, yaitu "Garuda di Dadaku", bagaimana Simbol Negara itu begitu penting dan ingin ditunjukkan pada dunia.

Keberadaan jaket GO-JEK dan segala atributnya kini menjamur dimana-mana. Hal ini menunjukkan sisi lain fashion, dimana bukan hanya sebagai ajang untuk bergaya dan menentukan kelas, melainkan membuka lapangan pekerjaan baru. Industri fashion menjadi industri yang tidak pernah mati karena selalu ada pembaruan di sana. Barangbarang tiruan yang akhirnya menjadi merchandise dari GOJEK ini memberikan kesempatan bagi insan-insan kreatif 
National Conference of Creative Industry: Sustainable Tourism Industry for Economic Development

Universitas Bunda Mulia, Jakarta, 5-6 September 2018

ISSN No: 2622-7436

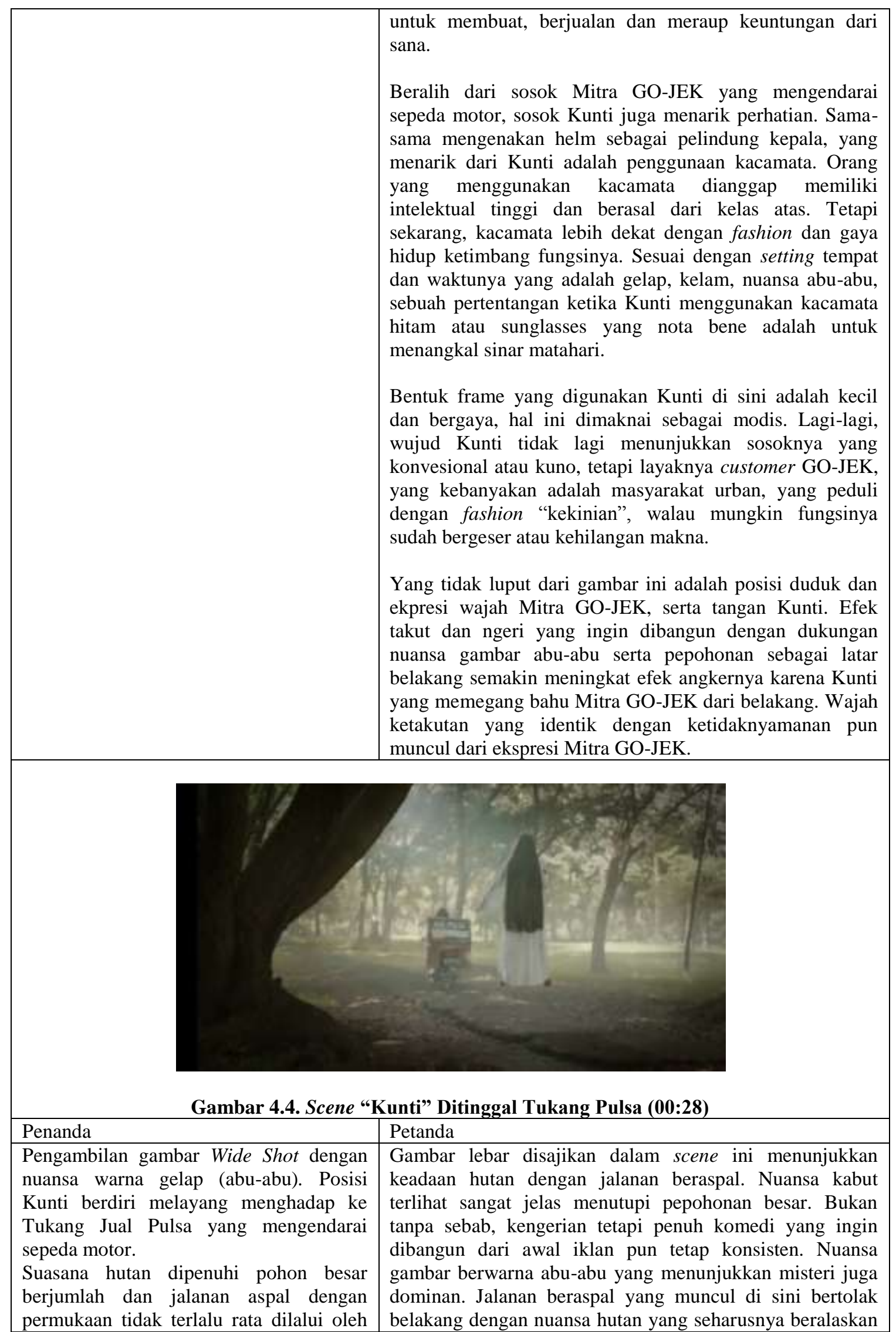


National Conference of Creative Industry: Sustainable Tourism Industry for Economic Development

Universitas Bunda Mulia, Jakarta, 5-6 September 2018

ISSN No: 2622-7436

tukang jual pulsa yang membawa gerobak berwarna coklat di sisi belakang. tanah saja. Hal ini dimaknai sebagai kemudahan jalanan yang dilalui Tukang Jual Pulsa tidak menjadi jaminan bahwa ia bisa mengakomodir semua kebutuhan dari Kunti (customer).

Warna cokelat yang menjadi warna gerobak Tukang Jual Pulsa juga tidak luput dari pemaknaan. Yaitu membumi, alami, suasana asli, dan keadaan konstan. Digunakan oleh Tukang jual Pulsa yang konvensional, tanpa sadar ini menggiring pemaknaan bahwa metode pembelian pulsa zaman dahulu sudah layak ditinggalkan. Datang ke gerai, menyebutkan nomor yang akan diisi, membeli menggunakan uang tunai, belum lagi ada resiko kegagalan. Rasanya cara itu menjadi kuno dan repot dilaksanakan.

Kunti yang dibangun sebagai Makhluk halus yang manusiawi memiliki kebutuhan yang sama akan pulsa serta kuota. Hal ini juga yang identik dengan masyarakat zaman sekarang, dimana Handphone serta internet menjadi kebutuhan pokok yang tidak bisa dilepaskan. Kebutuhan itu akan terjadi sepanjang hari dan terus menerus, tidak peduli pukul berapa dan dimana pun, kebutuhan ini akan terus ada. Analogi antara Kunti dengan customer GO-JEK ini turut mengantarkan pada kenyataan yang tertera di gambar, yaitu Kunti memiliki kebutuhan akan pulsa.

Mengusung diri sebagai on-demand mobile platform, GOJEK menunjukkan diri bisa mengakomodir kebutuhan akan apa saja kapan saja. Seperti yang terlihat pada iklan, pohon besar dan suasana malam hari identik dengan kebeadan hantu, kriminalitas yang tinggi, serta kesulitan mencari yang dibutuhkan. Warga mungkin menjadi lebih waspada dan hati-hati ketika malam menjelang tetapi pulsa dan kuota menjadi kebutuhan mendesak yang harus dipenuhi saat itu juga. Kunti pun memperkenalkan layanan GOPULSA yang bisa dijadikan Favorit, dimana customer GOJEK bisa melakukan pembelian pulsa tanpa hambatan apapun.

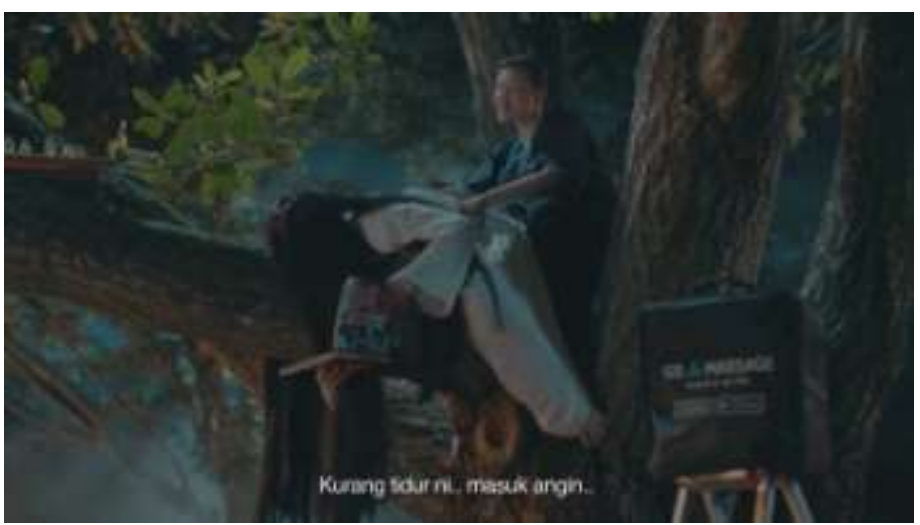

Gambar 4.5. Scene "Kunti" Dipijat (00:37)

Penanda Petanda

Pengambilan gambar Wide Shot dengan Mistisme dan Inovasi tidak luput ada di iklan "GO-JEK nuansa warna gelap (abu-abu). Posisi Versi Kamu" episode "Kunti". Pengambilan gambar adalah 
Kunti telungkup tidur di atas pohon sambil dipijat oleh Ibu dari layanan GOMASSAGE. Kunti membuka majalah dan membacanya dengan serius. Penampakan Kunti adalah dengan rambut panjang, pakaian putih, sementara Ibu Pijat menggunakan pakaian berwarna biru dongker dengan list biru muda. Terdapat properti tas GO-MASSAGE di sisi kiri Ibu Pijat.
Wide Shot. Hal ini untuk menunjukkan keseluruhan setting yang ada di dalam adegan tersebut. Yang utama ingin ditujukan di sini adalah ketidak biasaan ketika melakukan pemijatan di atas dahan pohon.

Baju putih yang digunakan Kunti tidak mengalami pergeseran dari scene awal, yaitu bermakna kesucian serta kesopanan. Rambut panjang yang ada pada dirinya pun masih tetap sama. Yang berbeda kali ini adalah properti yang melekat pada diri Kunti. Apabila pada scene sebelumnya Kunti menggunakan handphone sebagai pendukung dirinya yang begitu kekinian, pada scene ini, Kunti menggunakan majalah yang semakin mendekatkan dirinya dengan keadaan customer GO-JEK pada umumnya.

Majalah merupakan salah satu media massa cetak yang disukai golongan tertentu. Mengapa demikian? Hal ini lantaran setiap majalah memiliki segmentasi atau cakupan pembahasan serta audiens sendiri yang berbeda satu sama lain. Majalah berisi gambar atau foto yang lebih dominan ketimbang tulisan. Hal ini juga yang membedakan majalah dengan media massa cetak lain seperti koran, dimana koran lebih mengutamakan isi berita ketimbang atribut pelengkap seperti foto atau hiasan lain. Mayoritas Majalah berisi informasi mengenai hobby, sementara mayoritas koran berisi informasi yang seriu dan bersifat segera seperti ekonomi, politik, dan lainnya.

Karena hal ini juga, membaca majalah identik dengan waktu bersantai. Pemaknaan yang timbul dari gambar di durasi 00:37 adalah Kunti berada dalam posisi lelah setelah harus melalui hari, maka ia ingin merasakan waktu "dimanjakan". Selama ini, ketika ingin merasakan pijatan yang pas dan harga sesuai di kantong, masyarakat (urban terutama) wajib datang ke tempat pijat atau refleksi yang begitu banyak tersebar di kota besar. Tetapi dengan kehadiran GO-MASSAGE, hal ini tidak diperlukan lagi, lantaran terapis yang dibutuhkan atau diinginkan bisa dengan mudahnya datang menghampiri dan memberikan jasanya kepada customer.

Kemudahan dalam ketidakbiasaan tergambar jelas dalam gambar ini. Kegiatan memijat yang lazimnya dilakukan di sebuah kamar dengan alas kasur empuk serta suasana ruangan yang membuat rileks, tidak tergambar. Yang justru ingin dikedepankan oleh layanan GO-MASSAGE adalah bisa memijat siapa saja dan kapan saja, tanpa peduli tempat yang mungkin tidak mumpuni seperti Kunti yang dipijat di dahan pohon sekalipun.

Posisi duduk Ibu Pijat yang terlihat kurang nyaman ini pun tidak menjadi penghalang untuk memberikan pelayanan kepada customernya (Kunti). Dengan senyum dan pijatan yang terlihat nikmat, ia juga mengajak Kunti berbincang. Nilai ini yang ingin diusung oleh GO-JEK terutama dalam layanan GO-MASSAGE. Hal ini relevan dengan warna baju yang menjadi warna utama dari Ibu Pijat GO- 
National Conference of Creative Industry: Sustainable Tourism Industry for Economic Development

Universitas Bunda Mulia, Jakarta, 5-6 September 2018

ISSN No: 2622-7436

\begin{tabular}{|c|c|}
\hline & $\begin{array}{l}\text { MASSAGE, yaitu Biru dongker. } \\
\text { Warna Biru identik dengan harapan, langit, surga, dan } \\
\text { ketenangan. Ketika memesan layanan pijat, yang dicari } \\
\text { oleh customer adalah bisa kembali fresh ketika beraktivitas. } \\
\text { Hal ini yang diusung oleh layanan GO-MASSAGE, yaitu } \\
\text { memberikan ketenangan kepada pelanggannya. } \\
\text { Identitas GO-MASSAGE tetap dimunculkan dalam scene } \\
\text { ini. Walaupun tidak dominan dan hanya berada di sisi kiri } \\
\text { Ibu Pijat, tas GO-MASSAGE tetap terlihat. Menggunakan } \\
\text { warna Hitam sebagai warna utama dalam tas tersebut, } \\
\text { tulisan GO-MASSAGE berwarna putih terlihat Kontras. } \\
\text { Bukan tanpa sebab, hal ini disebabkan, iklan tetap ingin } \\
\text { menonjolkan bahwa kelebihan dari layanan GO-JEK } \\
\text { adalah GO-MASSAGE yang bila dikaitkan dengan } \\
\text { pemaknaan warna putih adalah menunjukkan kesucian, } \\
\text { kebaikan, dan kesopanan. } \\
\text { Seperti diketahui, layanan pijat seringkali dikaitkan dengan } \\
\text { hal lebih, maka tidak jarang kita mendengar istilah "pijat } \\
\text { plus plus" atau lainnya yang berkonotasi negatif. Apalagi } \\
\text { bila dikaitan dengan pemanggilan "Tukang Pijat" ke } \\
\text { rumah, tidak dipungkiri konotasi itu akan terpikir. Dengan } \\
\text { menggunakan tas yang memiliki identitas dengan tulisan } \\
\text { berwarna putih, tidak dipungkiri hal ini akan membentuk } \\
\text { citra baru, dimana layanan pijat GO-MASSAGE juga tetap } \\
\text { mengutamakan kesucian, kebaikan, dan kesopanan. }\end{array}$ \\
\hline Gambar 4.6. Scene & "Kunti" Terima GO-FOOD (00:46) \\
\hline Penanda & Petanda \\
\hline $\begin{array}{l}\text { Pengambilan gambar Wide Shot dengan } \\
\text { nuansa warna gelap (abu-abu). Posisi } \\
\text { Kunti duduk di dahan pohon dengan kaki } \\
\text { menggantung. Ia terlihat sedang } \\
\text { menghitung daun yang dianggap sebagai } \\
\text { uang dan akan diberikan kepada Mitra } \\
\text { GO-JEK. } \\
\text { Dari scene ini juga terlihat mitra GO-JEK } \\
\text { yang sedang memberikan kantung plastik } \\
\text { bening berisi makanan kepada Kunti. } \\
\text { Posisi mitra GO-JEK di bawah Kunti dan } \\
\text { duduk di atas motor dengan wajah }\end{array}$ & $\begin{array}{l}\text { Kunti kembali menunjukkan tampilannya sebagai sosok } \\
\text { yang mirip manusia atau dalam hal ini, layaknya customer } \\
\text { GO-JEK yang selalu ingin dipenuhi kebutuhannya. Setelah } \\
\text { menggunakan layanan GO-RIDE, GO- PULSA, dan GO- } \\
\text { MASSAGE, kebutuhan akan makanan tidak dipungkiri } \\
\text { juga menjadi penting dalam hal ini, } \\
\text { Teknologi yang semakin maju berkaitan erat dengan warga } \\
\text { Urban zaman sekarang yang selalu ingin dimudahkan. } \\
\text { Bepergian, bayar membayar transaksi bulanan, hingga } \\
\text { membeli makanan menjadi hal yang begitu lekat sehari- } \\
\text { hari. Layanan GO-FOOD akhirnya menjadi jawaban bagi }\end{array}$ \\
\hline
\end{tabular}


menghadap ke bawah (tidak melihat ke Arah Kunti). mereka yang ingin membeli makanan dari restaurant yang jauh atau justru dekat tetapi "malas antri". Kemudahan semakin besar ketika ada juga GO-PAY yang menghilangkan fungsi dari uang tunai. Hal ini merupakan pemaknaan dari daun yang dipegang Kunti. Analogi daun itu adalah adalah uang tunai yang pada scene selanjutnya dibuang oleh Kunti.

Kunti duduk di atas dahan pohon adalah suatu hal yang biasa, tetapi Kunti memesan makanan dan meminta Mitra GO-JEK mengantarkan makanan tersebut adalah hal yang di luar kebiasaan. Hal ini yang menjadi konsep utama dari scene ini. Siapapun pasti pernah merasa lapar, bahkan ketika malam hari, maka GO-FOOD di sini menjadi solusi. Tempat duduk Kunti yang sulit dijangkau dianalogikan sebagai lokasi customer GO-FOOD yang bisa tersebar dimana saja dan memesan menu apa saja, tidak peduli jam berapapun itu.

Membahas mengenai Mitra GO-JEK, di sini ia menggunakan jaket GO-JEK berwarna hijau dan motor yang juga berwarna hijau. Identitas tidak ingin ditinggalkan, dimana warna hijau lekat arti dengan keterus terangan, kepercayaan, kehidupan, eksistensi.

Keseluruhan gambar sama seperti dengan scene sebelumnya, dimana menggunakan unsur gelap atau abuabu yang mengandung misteri sebagai elemen utamanya. Bukan lagi mengutamakan kedekatan publik atau konteks seperti yang tergambar dalam medium shot, di scene awal. 
National Conference of Creative Industry:

Sustainable Tourism Industry for Economic Development

Universitas Bunda Mulia, Jakarta, 5-6 September 2018

ISSN No: 2622-7436

\title{
4.1.2. Pesan Ikonik yang Tak Terkodekan "Kunti" dalam iklan "GO-JEK Versi Kamu"
}

Untuk melengkapi sajian signifikasi dua tahap dalam pisau analisis Roland

Barthes, berikut akan dipaparkan pesan ikonik yang tak terkodekan yaitu denotasi harafiah atau pemahaman langsung dari gambar, tanpa mempertimbangkan kode sosial yang lebih luas.

Tabel 4.2.

Pesan Ikonik Tak Terkodekan "Kunti” dalam iklan "GO-JEK Versi Kamu”

\begin{abstract}
Pesan Ikonik Tak Terkodekan - "Kunti”
GO-JEK adalah sebuah perusahaan teknologi berjiwa sosial yang bertujuan untuk meningkatkan kesejahteraan pekerja di berbagai sektor informal di Indonesia. Kegiatan GO-JEK bertumpu pada 3 nilai pokok: kecepatan, inovasi, dan dampak sosial. Hal yang divisikan oleh GO-JEK relevan dengan kemajuan teknologi zaman sekarang, dimana masyarakat menginginkan hal yang cepat dan mudah.
\end{abstract}

GO-JEK terus menerus memberikan inovasi dan kemudahan kepada penggunanya. Hal ini disajikan dalam ragam iklan yang disajikan. Ada iklan terkait layanan Menu Terserah GO-FOOD, Penggunaan GO-PAY yang memudahkan transaksi, dan yang terbaru adalah menyusun layanan favorit. Setiap iklan memiliki ciri dan tujuan tersendiri, juga segmentasi sendiri, sama halnya dengan Iklan "GO-JEK Versi Kamu” Episode Kunti.

Iklan berdurasi 1 menit ini dimulai dengan tampilan layar hitam dan tulisan hijau "Kunti Mencari Anak". Scene selanjutnya menunjukkan sosok Kunti yang berdiri melayang menggunakan baju putih dan rambut panjang hingga menyentuh paha. Kunti ini terlihat menyeramkan seperti makhluk halus pada umumnya, tetapi gerakan yang dia lakukan menyerupai manusia normal. Cerita dilanjutkan dengan Kunti mendengar Notifikasi dari Handphone yang menyatakan adanya update dari GO-JEK. Kunti langsung mengambil Handphone tersebut, lalu layar handphone Kunti menunjukkan aplikasi GO-JEK dan bisa menyusun kategori layanan mana yang akan ditempatkan paling atas.

Kunti memilih GO-RIDE sebagai aplikasi pertama yang ia jadikan favorit, dilanjutkan dengan adegan Kunti mengenakan helm dan kacamata hitam menjadi penumpang dari Mitra GO-JEK. Kunti merangkul atau memeluk Mitra GO-JEK dari belakang, ekspresi wajah Mitra GO-JEK terlihat sangat ketakutan dan tidak nyaman dengan pelukan tersebut.

Scene selanjutnya menceritakan Kunti yang memilih layanan GO-PULSA lantaran Tukang Pulsa yang "suka kabur" ketika melihat Kunti. Hal ini didukung dengan scene selanjutnya yaitu Tukang Pulsa yang kabur sambil mengendarai sepeda motor dengan gerobak coklat di belakangnya. Hal ini bersamaan dengan Kunti yang muncul sambil menggantung di dahan pohon.

Tidak berhenti di sana, kemampuan Kunti menggunakan handphone semakin ditunjukkan ketika ia memilih layanan GO-MASSAGE sebagai layanan favorit ke-3. Tidak seperti Tukang Pulsa yang kabur, Ibu Pijat dari GOMASSAGE malah tersenyum senang sambil mengobrol dengan Kunti, walau memijat dalam posisi yang tidak biasa, yaitu di atas dahan pohon. Kunti pun membaca majalah, sebagai tanda ia menikmati pijatan tersebut.

Selanjutnya, GO-FOOD menjadi pilihan Kunti untuk dimasukkan dalam layanan favoritnya. Sambil meng-scroll ke bawah, Sate menjadi pilihan Kunti. Scene selanjutnya menceritakan bagaimana Mitra GO-JEK datang dan memberikan Kunti makanan tersebut tetapi Kunti berada di atas pohon.

Yang menarik dari iklan ini adalah sosok makhluk halus yang menjadi talent utama. Sosok Kunti di sini sama seperti makhuk halus pada umumnya, tetapi melakukan gerakan manusia. Suatu hal yang jarang terjadi, manakala makhluk mistis yang dahulu identik dengan hal menyeramkan, klenik dan dijauhi, justru menjadi subjek utama dari iklan perusahaan besar.

Selain tampilan Kunti, yang juga dominan dalam tayangan ini adalah warna hijau yang berasal dari Jaket GO-JEK. 
National Conference of Creative Industry:

Sustainable Tourism Industry for Economic Development

Universitas Bunda Mulia, Jakarta, 5-6 September 2018

ISSN No: 2622-7436

Dalam scene yang dikaji peneliti, Mitra GO-JEK muncul sebanyak 2x, yaitu di scene GO-RIDE dan GO-FOOD. Warna yang menjadi dominan dalam hal ini adalah hijau, sangat kontras dengan latar belakang gambar yang dominan warna gelap, seperti coklat pada dahan pohon, hitam pada aspal, atau kabut berwarna abu. 
National Conference of Creative Industry:

Sustainable Tourism Industry for Economic Development

Universitas Bunda Mulia, Jakarta, 5-6 September 2018

ISSN No: 2622-7436

\subsection{Mitologi}

Pergeseran makna tanda disebut sebagai mitologi yang merupakan wahana dimana ideologi berwujud. Tanda yang dibuat tanpa sengaja dalam kehidupan sehari-hari, nyatanya menyimpan ideologi yang membuat adanya perubahan makna dari dulu sampai sekarang yang erat kaitannya dengan budaya, konteks, ataupun faktor subjektif lainnya. Mitologi tidak pernah netral dan selalu ada dalam setiap tanda untuk membantu pembaca menggambarkan situasi sosial budaya dan politik yang ada disekelilingnya. Ia bertugas memainkan pesan-pesan tertentu yang boleh jadi berbeda sama sekali dengan makna asalnya.

Menurut Barthes, mitos adalah tipe wicara, sistem komunikasi dan sebuah pesan. Mitos tidak bisa menjadi sebuah objek, konsep atau ide. Mitos adalah bentuk cara penandaan yang identik dengan "perampokan bahasa". Dari sekian banyak tanda nonverbal yang terpapar dalam Iklan "GO-JEK Versi Kamu” Episode "Kunti", peneliti membagi dalam 2 mitologi, antara lain :

1. Mitologi Gaya Hidup

Kehidupan telah berubah, komunikasi, industri, teknologi, dan inovasi telah mengalami pergeseran makna, dari kebutuhan sekunder menjadi kebutuhan primer terutama bagi mereka yang berada di lingkungan perkotaan. Terpaan media massa konvensional dan media baru seperti internet tidak hanya menyerang dalam lingkup pikiran sehingga membuat penerima memiliki suatu pandangan tersendiri akan fenomena. Lebih jauh hal ini juga terkait dengan gaya hidup.

Proses ini terjadi secara simultan bolak balik antara media yang mempengaruhi masyarakat, dengan masyarakat yang menentukan hal apa yang menjadi viral atau booming di keseharian. Proses ini biasa berjalan dari public figure yang memiliki suatu kegiatan dan kegemaran tertentu dan ditunjukkan di sosial media, akhirnya dianggap sebagai suatu hal yang lumrah, sampai menjadi kebiasaan juga di kalangan masyarakat biasa. Maka pergeseran yang berkaitan erat dengan gaya hidup mendominasi keberadaan makna-makna baru yang muncul dalam gambar iklan "GO-JEK Versi Kamu" Episode "Kunti" berjalan terus menerus beriringan dengan dinamisasi dari masyarakat.

\section{Mitologi Transformasi Makna}

Pergeseran makna bukan hal yang asing terjadi dalam kaitannya dengan sebuah tanda. Kata "transformasi" sendiri bermakna adanya perubahan makna dari yang lama menjadi yang baru, dengan tetap membawa unsur dari makna aslinya. Bukan tanpa sebab, pergeseran ini terus terjadi lantaran ada terpaan dari media massa konvensional maupun media sosial yang akhirnya membuat masyarakat memiliki kesadaran baru, tanpa meninggalkan kesadaran lama yang telah terbentuk sebelumnya. Proses ini tidak pernah berlangsung sekali jalan, melainkan terus menerus, tidak pernah jenuh lantaran akan terus bermunculan makna baru di masyarakat akam sebuah tanda. Tidak dipungkiri kemampuan media massa yang sangat berpengaruh besar, membuat transformasi ini kian dinamis walaupun kadang tidak stabil dan menemui kebuntuan.

\subsubsection{Mitologi Gaya Hidup}


National Conference of Creative Industry:

Sustainable Tourism Industry for Economic Development

Universitas Bunda Mulia, Jakarta, 5-6 September 2018

ISSN No: 2622-7436

\section{a. Handphone}

Keberadaan handphone dalam kehidupan sehari-hari tidak bisa dipungkiri sudah sangat melekat. Dahulu dianggap sebagai sarana untuk mempermudah komunikasi jarak jauh, tetapi sekarang lebih jauh, handphone layaknya identitas yang melekat pada diri pemiliknya. Kelas sosial seseorang kadang dinilai dari merk dan tipe handphone yang digunakan, eksistensi seseorang dalam dunia maya terutama, ditentukan oleh seberapa banyak post nya di sosial media, juga berapa banyak followers dan likers nya. Perkembangan handphone yang semakin primer, sejalan dengan perkembangan teknologi yang semakin maju, dan pastinya menjamurnya internet sebagai pendamping setia.

Mengusung perubahan gaya hidup ini, tidak heran semakin banyak aplikasi yang dibuat dan mudah didapat di dalam jagad maya. GO-JEK adalah salah satunya. Dengan pengguna lebih dari 10 Juta orang, GO-JEK menjadi aplikasi karya anak bangsa yang begitu sering digunakan lantaran di dalamnya bukan hanya membantu dalam hal transportasi, melainkan juga kurir antar barang, pembelian makanan, tiket, dan lain-lain.

Penggunaan Properti handphone oleh talent utama yaitu Kunti di sini menunjukkan bagaimana handphone sebegitu dekat dengan kehidupan manusia sehari-hari. Dianalogikan di sini bahwa sosok makhluk halus yang begitu konvensional dan jauh dari dunia gadget saja menggunakan handphone dan aplikasi GO-JEK di dalamnya. Jadi tidak ada alasan bagi masyarakat zaman sekarang (kaum urban terutama), untuk tidak menggunakan aplikasi ini, apalagi dengan keunggulan terbaru dimana bisa menyusun sendiri, layanan mana yang dijadikan favorit dan akan diletakkan di bagian atas.

\section{b. Kacamata}

Kacamata bukan lagi sekedar alat bantu melihat, melainkan ajang bergaya. Banyak yang menganggap alat ini hanya sekedar aksesoris yang dipakai untuk melengkapi penampilan yang polos. Walaupun dikategorikan sebagai orang yang "culun", "nerd", dan istilah lain yang intinya menggunakan kacamata adalah sesuatu yang tidak keren, kacamata tetap dicintai karena dapat merubah pandangan orang terhadap penampilan yang berakibat pada pembacaan karakteristik secara keseluruhan. Orang yang menggunakan kacamata seringkali dianggap sebagai orang yang pintar, karena kacamata berkaitan dengan kerusakan mata akibat aktifitas membaca yang terlalu sering, hobby membaca dalam posisi tidur dan di tempat gelap, sampai dengan banyaknya buku yang telah dibaca. Sebegitu luasnya makna yang disajikan oleh kacamata, merujuk pada kesan bahwa orang yang mengenakan kacamata adalah orang yang pintar dan rajin, maka dari itu banyak orang yang ingin dikatakan demikian, dengan jalan pintas yaitu menggunakan kacamata.

Dalam sajian iklan "GO-JEK Versi Kamu" Episode "Kunti", kacamata hitam atau anti sinar matahari digunakan oleh Kunti ketika menaiki tumpangan GO-RIDE. Bukan suatu kewajaran manakala kacamata tersebut bukan untuk melihat atau membaca, melainkan untuk bergaya saja. Mengapa demikian? Hal ini lantaran suasana sekeliling Kunti dan mitra GO-JEK saat itu adalah gelap (setting malam hari), sementara Kunti menggunakan Kacamata hitam yang justru membuat semakin gelap. Hal ini dikaitkan dengan kehidupan zaman sekarang, dimana seringkali orang justru melakukan hal memaksakan gaya walau kadang tidak sesuai.

\section{c. Fashion}


Pembaruan dalam dunia Fashion identik dengan kemunculan lapangan kerja bagi banyak orang, mulai dari perancang busana, photographer, perias wajah dan rambut, model, penjahit, konveksi, sampai dengan pengecer. Setiap elemen ini saling membutuhkan, hingga membangun lingkaran penuh makna yang tidak boleh terputus. Bukan hanya untuk kalangan kelas atas saja, nyatanya Fashion juga memberikan keuntungan bagi kalangan kelas menengah ke bawah yang mampu menjual barang tiruan beserta aksesorisnya dengan harga murah dan terjangkau sehingga dapat dinikmati oleh semua kalangan.

Tidak hanya yang berkaitan langsung dengan keberadaan Fashion, nyatanya Fashion juga memberikan keuntungan bagi lokasi tempat toko Fashion berada (mall, toko baju, aksesoris, dan lainnya), juga keberadaannya dalam dunia online, seperti situssitus dan pihak-pihak tertentu yang bekerja dalam pengoperasian dunia siber.

Dalam iklan "GO-JEK Versi Kamu" Episode "Kunti", fashion muncul di sini tergambarkan dari jaket yang digunakan oleh Mitra GO-JEK. Jaket yang selama ini dianggap dan digunakan sebagai pelindung dari hujan, angin atau matahari, akhirnya beralih fungsi menjadi sebuah identitas dari pemakainya. Tidak jarang kita melihat segerombolan orang yang berkumpul menggunakan jaket yang sama. Tanpa sadar, rasa solidaritas, senasib dan sepenanggungan dan merasa lebih kuat daripada ketika berdiri sendiri muncul.

Selain Jaket, GO-JEK dan segala pernak perniknya menjadi item merchandise yang booming juga. Mulai dari topi, kaos, kipas, hingga helm yang akhirnya dicari bukan hanya oleh Mitra - nya saja, melainkan orang biasa yang merasa hal itu adalah keren dan berbeda dari fashion pada umumnya.

\subsubsection{Mitologi Transformasi Makna}

a. Mistis

Makhluk halus dahulu menjadi sosok yang menyeramkan dan dihindari oleh masyarakat. Mereka identik dengan horor mistis yang menakutkan dan tidak bisa dikontrol dalam kehidupan nyata. Hal ini berbeda sama sekali dengan sosok Kunti dalam Iklan "GO-JEK Versi Kamu". Sosoknya menjadi begitu manusiawi dan bisa diterima dengan baik oleh audience dari iklan tersebut.

Analogi yang ingin disampaikan dalam iklan "GO-JEK Versi Kamu” ini adalah Kunti merupakan makhluk halus yang sukar ditebak terkait apa yang diinginkan. Tetapi dengan fitur terbaru dari GO-JEK yaitu menyusun sendiri layanan apa yang ingin dijadikan favorit, maka customer juga akan dimudahkan, tidak usah mencari-cari lagi apabila ingin menggunakan.

Iklan adalah suatu sarana untuk memperkenalkan produk dan biasanya memiliki ciri khas sendiri. Dalam hal ini iklan "GO-JEK Versi Kamu" Episode "Kunti" memgambil tema mistis sebagai konsep utamanya. Hal ini identik dengan simbol lain yang merujuk pada suasana mistis, seperti pencahayaan remang, pepohonan lebat, kabut, dan unsur seram lainnya. Tidak ada warna-warna meriah seperti merah, pink, biru muda, ataupun silver dan emas, semua tergantikan dengan keberadaan warna yang lebih tenang dan "adem" serta menghangatkan. Hal ini semakin lengkap dengan keberadan sosok Kunti "Gaul" yang tenang dan kalem dalam melakukan aktifitasnya dengan aplikasi GO-JEK, sehingga penggempuran nuansa mistis yang ingin dibangun terealisasi secara nyata dalam tayangan ini. 


\section{c. Gaya Memegang Handphone}

Dalam aktifitas keseharian, cara memegang handphone tidak terlalu diperhatikan bahkan dianggap tidak terlalu penting. Hal ini nyatanya salah lantaran gaya memegang handphone menjadi suatu tanda tersendiri yang mengungkapkan makna khusus. Kunti dalam iklan ini adalah subject utama yang seringkali memegang handphone dengan satu tangan. Hal ini menyatakan bahwa ia memiliki kebutuhan khusus yang ingin sekali diakomodir.

Bukan sekedar ingin menunjukkan aplikasi yang sedang digunakan, nyatanya gaya memegang handphone dengan salah satu tangan ini dianalogikan dengan keberadaan customer di masyarakat luas yang memiliki gaya dan kebutuhan yang beragam. Keinginan itu berusaha maksimal diakomodir oleh GO-JEK dengan salah satu layanan yang diluncurkan yaitu menyusun sendiri "Versi Kamu". 
National Conference of Creative Industry:

Sustainable Tourism Industry for Economic Development

Universitas Bunda Mulia, Jakarta, 5-6 September 2018

ISSN No: 2622-7436

\section{BAB V \\ KESIMPULAN \& IMPLIKASI}

Berdasarkan hasil penelitian dan pembahasan mengenai makna verbal dan nonverbal serta mitologi dalam iklan "GO-JEK Versi Kamu” Episode "Kunti", maka berikut ini adalah kesimpulan dan implikasi yang bisa dipaparkan :

\subsection{Kesimpulan}

Tanda verbal dan nonverbal menjadi begitu penting dan nyata dalam iklan ini. Setting tempat, efek gambar, properti, wardrobe, hingga teknik pengambilan gambar pun mengungkapkan makna bahwa layanan GO-JEK terasa mudah dan dekat dengan penggunanya.

Iklan "GO-JEK Versi Kamu" Episode "Kunti" merupakan suatu wujud iklan yang mengedepankan keberadaan makhluk mistis di dalamnya sebagai perwakilan dari customer GO-JEK yang begitu beragam dan memiliki kemauan berbeda satu sama lain. Hal ini tergambarkan dari Kunti yang memegang handphone dan memilah-milah layanan yang akan ia gunakan, layaknya customer pada umumnya, dengan segala kebutuhan dan kemauannya.

Kunti di dalam iklan ini bukan menjadi sosok yang menyeramkan dan dijauhi oleh manusia normal, melainkan menjadi sosok yang begitu dekat dengan kehidupan seharihari dan selalu dilayani kebutuhannya. Kunti dianalogikan sebagai sosok yang punya "banyak mau" dan misterius serta kadang sulit dimengerti kemauannya. Tetapi dengan layanan dan aplikasi yang tepat, GO-JEK di sini mampu mengakomodir itu semua.

Terdapat juga pergeseran makna tanda dalam iklan ini. Yang paling banyak mengalami pergeseran itu adalah berasal dari pihak Kunti, baik itu gerakannya serta properti ataupun aksesoris yang digunakan. Selain itu, nuansa mistis juga mengalami peralihan makna. Hal ini tergambar dalam mitologi Gaya Hidup yang mencakup Handphone yang digunakan oleh Kunti, Kacamata sebagai pelengkap berkendara, serta dari sisi fashion yaitu jaket serta atribut GO-JEK yang semakin marak di Indonesia. Untuk nuansa mistis dan gerak gerik dari Kunti sendiri dirangkum dalam Mitologi Transformasi makna, dimana mistis dan gerakan makhluk halus bukan lagi suatu hal yang menyeramkan, melainkan menunjukkan sisi kemanusiaan dari makhluk tersebut yang lebih kurang memiliki persamaan sikap dengan customer GO-JEK pada khususnya.

\subsection{Implikasi}

Melihat konsep iklan yang ditawarkan "GO-JEK Versi Kamu" Episode "Kunti", maka peneliti menyarankan keunikan iklan harus tetap dijaga. Setelah mengambil tema mistis, suasana announcement bioskop, hingga robot sebagai bintang utamanya, tema lain yang dekat dengan masyarakat juga layak dikedepankan. Hal ini tidak lain lantaran GO-JEK adalah aplikasi yang digunakan dalam kehidupan sehari-hari, sehingga akan lebih mudah diterima gencaran informasinya, bila dikaitkan dengan hal yang ada di sekeliling customer atau pengguna GO-JEK 
National Conference of Creative Industry: Sustainable Tourism Industry for Economic Development Universitas Bunda Mulia, Jakarta, 5-6 September 2018

ISSN No: 2622-7436

\section{DAFTAR PUSTAKA}

Ardianto, Elvinaro. (2004). Komunikasi Massa: Suatu Pengantar. Bandung: Simbiosa Rekatama Media.

Barthes, Roland. (2009). Mitologi. Yogyakarta: Penerbit Kreasi Kencana. . (2010). Imaji/ Musik/ Teks. Yogyakarta: Penerbit Jalasutra.

Danesi, Marcel. (2010). Pesan, Tanda, dan Makna : Buku Teks Dasar Mengenai Semiotika dan Teori Komunikasi. Yogyakarta: Penerbit Jalasutra. (2010). Pengantar Memahami Semiotika Media. Yogyakarta: Penerbit Jalasutra.

Daymon, C., \& Holloway, I. (2008). Riset Kualitatif dalam Public Relations dan marketing Communications. Yogyakarta: Bentang.

Duncan, T. (2005). Principles of Advertising \& IMC. New York: The Mc Graw Hill.

Eriyanto. (2008). Analisis Wacana: Pengantar Analisis Teks Media. Yogyakarta: Penerbit LkiS.

Littlejohn, Stephen W. dan Foss, Karen A. (2009). Theories of Human Communication. Terjemahan Mohammad Yusuf Hamdan. Jakarta: Penerbit Salemba Humanika.

Moriarty, dkk. (2011). Advertising. Jakarta: Kencana Prenada Media Group.

Morissan. (2009). Manejemen Media Penyiaran: Strategi Mengelola Radio dan Televisi. Jakarta: Penerbit Kencana Prenada Media Group.

. (2010). Periklanan Komunikasi Pemasaran Terpadu. Jakarta : Kencana Prenada Media Group.

Sobur, Alex. (2003). Semiotika Komunikasi. Bandung: Rosda.

(2009). Analisis Teks Media : Suatu Pengantar untuk Analisis Wacana,

Analisis Semiotik, dan Analisis Framing. Bandung: Penerbit PT Remaja Rosda Karya.

Vivian, John. (2008). Teori Komunikasi Massa, Edisi Kedelapan. Jakarta: Penerbit Kencana. 